\title{
PROCEEDINGS OF THE
}

FOURTH INTERNATIONAL CONGRESS OF NEUROGENETICS AND NEUROOPHTHALMOLOGY 


\section{PROCEEDINGS OF THE \\ FOURTH INTERNATIONAL CONGRESS \\ OF NEUROGENETICS AND NEUROOPHTHALMOLOGY}

Rome: 25-28 September 1973

Sponsored by

The World Federation of Neurology - Research Committee

Organizing Committee:

Luigi Gedda (Roma), President

Jules François (Gand)

David Klein (Genève)

Marco Milani Comparetti (Ancona), Secretary General

Volume 23

ACTA GENETICAE MEDICAE ET GEMELLOLOGIAE

Cappelli editore - Bologna 1974 
International Standard Serial Number: 0001-5660

(C) 1974 by Acta Geneticae Medicae et Gemellologiae

Casa editrice Cappelli spa

Via Marsili 9, 40124 Bologna, Italy

Printed in Italy

Stabilimento Tipolitografico di Rocca San Casciano 


\section{CONTENTS}

Ix Foreword

\section{TAPETORETINAL DEGENERATIONS AND CNS GENETIC DISEASE}

3 Tapetoretinal Degenerations in Spinocerebellar Degenerations (Heredoataxias) by J. François

25 Tapetoretinal Degenerations and Disorders of Lipid Metabolism Part I: Clinical, Genetic, Pathological, and Therapeutic Aspects by S. Merin

33 Tapetoretinal Degenerations and Disorders of Lipid Metabolism Part II: Biochemical Aspects by E. R. Berman

49: Usher's and Hallgren's Syndromes by S. Merin, F. A. Abraham, E. Auerbach

\section{GENETIC COUNSELING AND THE DETECTION OF CARRIERS IN NEUROLOGY}

59 La Consultation Génétique en Neurologie Hérédité Mendélienne et Multifactorielle by P. Dodinval

83 Le Conseil Génétique dans les Aberrations Chromosomiques en Neurologie et en Ophtalmologie by J. M. Robert, C. Laurent, J. Pernod

103 Prenatal Genetics with Particular Reference to Neurological Disease by, H. ZeLLWEGER

115 Genetic Consultations in Neuroophthalmology by D. KLEIN

\section{GENFTICS OF DISORDERS OF NERVES AND SYNAPSES}

123 Neurotransmitters and Neuromodulators

by F. A. STeiner

\section{CHRONOGENETICS}

131 Chronogenetics

Its Foundations, Scope, and Impact

by L. GeDda, G. BRENCI

145 Some Biomedical Indicators in Chronogenetics

by M. Milani Comparetti, D. P. Pace, F. Britti, D. Casini

157 Systematics of the Age-Dependence of Some Neurological Disorders by P. R. J. Burch

\section{FREE CONTRIBUTIONS: First Group}

175 Tapetoretinal Degeneration in Three Mentally Retarded Sisters with Other Disorders in the Family Tree by J. JANCAR, R. M. WALTERS

181 Spinal Cord Involvement in Heritable Skeletal Dysplasias by A. B. Todorov, S. E. Kopits, G. B. Udyarhelyi

187 La Fonction Visuelle dans le Syndrome de Diabète Sucré, Diabète Insipide, Atrophie Optique et Dysacousie by J. R. Brunette, J. M. Little

191 Unusual Aspects of Goldenhar's Syndrome by A. Grignolo 
193 Ophthalmological Findings in Infantile Type of Neuronal Ceroid-Lipofuscinosis by Ch. RaitTa, P. Santavuori

197 Infantile Type of So-Called Neuronal Ceroid-Lipofuscinosis by P. Santavuori, M. Haltia, J. Rapola, Ch. Raitta, A. Keranen

201 Retinal Renal Dysplasia and Encephalopathy in a Patient with Triglyceride Storage Disease M. Philippart, W. den Tandt, C. Borrone, P. Durand

\section{FREE CONTRIBUTIONS: Second Group}

207 The Ethics of Genetic Counseling by S. O'Reilly

211 Genetic Counseling in X-Chromosomal-Linked Neuroophthalmological Diseases Status of the Female Heterozygote. Linkage and Crossingover with Xg Blood Group by J. F. Cuendet, B. Wuilleret

217 Homozygous Expression of a Dominant Gene Causing Peroneal Muscular Atrophy (Charcot-MarieTooth Disease) by H. W. Kloepfer, J. M. Killian

221 Prenatal Prediction of Autosomal Dominant Diseases by Linkage Studies: Myotonic Dystrophy by G. S. OMEnN, H. G. SChrotT

22.9 A Genetic Study of Chronic Spinal Muscular Atrophy by S. Bundey, R. E. Lovelace

233 Esperienze di Consulenza Eugenica in Neurologia all'Istituto Mendel by G. Del Porto, M. L. Tombolini

237 Myasthenia Gravis and the HL-A System

by E. van den Berg-Loonen, C. P. Engelfriet, T. E. W. Feltkamp, L. E. Nijenhuis, H. J. G. H. Oosterhuis, A. L. van Rossum, J. J. van Loghem

241 Genetic Studies of Acute Werdnig-Hoffmann Disease by J. H. PeARN

245 Hereditary Myopathy, Oligophrenia, Cataract, Skeletal Abnormalities, and Hypergonadotropic Hypogonadism: A New Syndrome by $\mathrm{P}$. O. LuNDBERG

249 Recessive Familial Spastic Paraplegia with Retinal Degeneration by W. Macrae, J. Stieffel, A. B. Todorov

253 A Case of Trisomy 8 by B. Dallapiccola, P. E. Gallenga, A. Pinca, L. Capra

259 Cariotipo XYY e Medulloblastoma by M. Rosano, M. Delellis, B. Massara, U. Ditondo, C. Casini

265 Analisi della Microsintomatologia nelle Malformazioni del S.N.C. by G. Del Porto, G. Brenci, M. L. Tombolini

\section{FREE CONTRIBUTIONS: Third Group}

271 Cronogenetica e Indice di Associazione by L. Gedda, G. Brenci, C. Di Fusco

275 Indice di Blastizzazione, Indice Mitotico e Indice di Riarrangiamento in Cronogenetica by L. Gedda, G. Brenci, G. Del, Porto, E. D'Alessandro, B. Di Tonto, L. Ciacci

281 La Distrofia Muscolare Progressiva: Aspetti Cronogenetici by G. Del Porto, G. Brenci

285 Accrescimento Ponderale in Gemelli nel Primo Anno di Vita by A. Alfieri, I. Gatti

289 Gene Decay

III. Mathematical Model of Back Mutations by C. Rossi

293 Age of onset and Evolution of Fabry's Disease by A. Th. Franceschetti Cronogenetica della Psoriasi by R. CAVAlieri 
303 Aspetti Genetici della Presbiacusia by L. GedDA, G. BRUNo

\section{FREE CONTRIBUTIONS: Fourth Group}

309 Meccanismo di Eccitazione Cerebrale e Pressione Endoculare in Consanguinei by $\mathrm{N}$. CinQuemani

315 The Characterisation of Individuals with Respect to Wilson's Disease by S. O'ReILLY

325 On the Epidemiology of Juvenile Amaurotic Idiocy in Denmark by K. Kristensen, H. Christensen Lou

329 Maladie de Refsum et Syndrome de Refsum by H. Petit

333 Comments to Dr. H. Petit's Communication on Refsum's Disease and Refsum's Syndrome by S. ReFsum

337 A Case of Beauvieux's Syndrome and its Evolution by A. M. Bardelli, A. Fois, R. Frezzotti

345 Asymptomatic Type II Hyperprolinemia Associated with Hyperglycinemia in Three Siblings by F. Mollica, L. Pavone, H. L. Levy

349 Physical and Mathematical Considerations About Laser Perimetry by L. FAVella, L. LiUzzi, F. BARToli

353 Laser Perimetry: Spatial Addition Analysis in the Papilloedema by F. BARTOLI, L. LiUzzI

357 Laser Perimetry: Comparison of Conventional and Laser Data in the Chiasmal Syndrome by F. BARTOLI, L. LIUZZI

363 Anomaloscopic Survey of Blue-Yellow Defects Among School Children in Santiago by R. Cruz-Coke, L. Rivera, J. Mardones, C. Y. Valenzuela

367 L'Importance de l'Electrophysiologie Rétinienne dans la Maladie de Batten-Mayou-Spielmeyer-Vogt (Ceroid Lipofuscinosis) by B. Stanescu, M. Spiritus, J. Michiels

371 Monoamine Oxidase Activity: A Genetic Marker of Schizophrenia? by F. OWEN, A. P. RIDges, I. B. COOKSON

377 Dominant Congenital Deafness and Progressive Optic Atrophy Report of a Family Through Four Generations by B. W. Konigsmark, D. L. Knox, I. F. Hussels, H. Moses 